\title{
ISABEL EMSLIE HUTTON'S ACCOUNT OF WORLD WAR I IN SERBIA
}

\begin{abstract}
Leaning on Maria Todorova's concept of Balkanism, this paper looks into an English travelogue from World War I - With a Woman's Unit in Serbia, Salonika and Sebastopol by a Scottish medical doctor Isabel Emslie Hutton - to show examples of the author's respect and sympathy for the Serbs as well as to point to what seems to be inevitable traces of Balkanism which go hand in hand with her expressions of appreciation and empathy. The paper argues that Balkanism seems to be overcome during Dr Hutton's five-year stay in Serbia and due to her first-hand experience with this country.
\end{abstract}

Key words: Isabel Emslie Hutton, Maria Todorova, Balkanism

The history of British travels to Serbia is long and eventful. The first travellers visited Serbia in medieval times, en route to the Holy Land (Kostić 1972: 7). Medieval times, of course, saw other British travellers through Serbia, mostly merchants, and in the following centuries, notably the eighteenth and the nineteenth, their number increased. They were of different professions, interests, education and motivation: soldiers, diplomats, scholars, clergymen, spies, as well as simply curious and adventurous individuals (Kostić 2014: 7). The beginning of the twentieth century and the appalling events of World War I brought to Serbia a special group of British travellers - medical doctors and nurses - who made an enormous effort to help ease, at least a little, the tragedy that befell Serbia, and who left written accounts of their work in this country. The professionals who established and ran the British medical missions did their jobs with utmost humanity, genuine empathy and true respect for the Serbs. The latter, true respect for the Serbs, so vividly present in their war travelogues, reveals an attitude strikingly contrary to the predominant British perception of the Serbian nation at the dawn of the twentieth century.

That perception was informed by what Maria Todorova in her famous book Imagining the Balkans (1999) names the concept of Balkanism. Balkanism is a negative stereotype about the Balkans typical of the Western culture and largely influenced by politics. The roots of Balkanism can be traced back to the first half of

\footnotetext{
Faculty of Philology, University of Belgrade, Studentski trg 3, 11000 Belgrade, Serbia; e-mail: m.spremickoncar@gmail.com
} 
the nineteenth century when Britain, following its own political interests and seeking to preserve the balance of power in the world, became engaged in giving resolute support to the territorial integrity of the Ottoman Empire, largely disregarding at the same time the dismal circumstances in which the Ottoman Empire's oppressed Christian subjects lived. Todorova claims (2009: 97) that the majority of the British aristocrats were Turcophile, while the liberal bourgeoisie was more sympathetic to the Christian peoples. She also notes that the British nineteenth-century travelogues can be said to reflect the country's official political standpoints: their authors, on the one hand, refrain from derogating the Turks (although they often criticize Ottoman authorities as wilful, despotic and uncivilized), while on the other hand they consider the South Slavs unable to successfully develop as independent nations. Early on in the twentieth century an unfavourable image of the Balkans as an underdeveloped and primitive, liminal region of Europe was already established and further tragic historical occurrences only reinforced it. The reputation of Serbia was severely compromised due to the regicide of King Aleksandar Obrenović and his Queen in Belgrade in May 1903 (Todorova 2009: 118) and Serbia was even declared responsible for Franz Ferdinand's assassination in Sarajevo and the consequent outbreak of World War I. Todorova also shows (2009: 119) that in war reports from the Balkans, notably German and Austrian, adjectives such as oriental and "Balkan" were widely used to denote negative features of the geographic region. "Oriental" was used to refer to "filth, passivity, unreliability, misogyny, propensity for intrigue, insincerity, opportunism, laziness, superstitiousness, lethargy, sluggishness, inefficiency, incompetent bureaucracy", while "Balkan" meant "cruelty, boorishness, instability and unpredictability". Opinions of this kind were numerous and widespread in the Western public and they had a key role in shaping a generally negative perception of this part of the world. Logically enough, positive views and impressions, unbiased by Balkanism, were rare, and travelogues written by members of several British medical missions in Serbia in World War I belong to that category. One of these deeply human and truly balanced accounts of war-stricken Serbia is Dr Isabel Emslie Hutton's book entitled With a Woman's Unit in Serbia, Salonika and Sebastopol, published in London in 1926. It was translated and published in Serbia only last year, under the title Sa ženskom jedinicom u Srbiji, Solunu i Sevastopolju. Its author, whose sense of duty and urge to help those in need made her leave her country to go to what she calls "gallant little Serbia" (Hutton 1928: 14) and whose humanitarian work put her own life in danger, got to know the Serbs well, learned their language, became familiar with their history and was thus able to understand their patriotism and love of freedom. That is why the story of Serbia offered in her book is in many ways incongruous with the then predominant discourse of Balkanism. In this paper I aim to show examples of Dr Hutton's respect and sympathy for the Serbs as 
well as point to what seems to be inevitable traces of Balkanism which go hand in hand with the author's expressions of appreciation and empathy.

Dr Isabel Emslie Hutton (1887-1960) was a Scottish medical doctor educated in Edinburgh. She specialized in psychiatry and held a position at the Royal Edinburgh Hospital. In 1915 she joined the Scottish Women's Hospitals Organization and served in Troyes, France, before she was relocated to Thessaloniki where her unit received news about going to Serbia. In the then Serbian town of Gevgelija (now in Northern Macedonia) they established a field hospital, but less than a month later, in early December 1915, following the upsetting news about the occupation of Serbia and its Army's retreat through Albania, they received an order to return to Thessaloniki. There, the hospital was put up once again and started receiving Serbian soldiers. From September 1916 Dr Hutton was engaged in another hospital, in the Greek town of Arnissa (Ostrovo), closer to the front. The Ostrovo hospital was directly adjoined to the Serbian Army and Dr Hutton was appointed its principal in January 1918. Upon the liberation of Macedonia and Serbia, gained by the joint Serbian and French forces from mid-September to early November 1918, Dr Hutton's hospital moved to Vranje, a town in southern Serbia, where her unit remained for a year, in the early days taking care of the soldiers and prisoners of war - Serbian, French, English, Bulgarian, Austrian and Italian - and, as the peaceful circumstances improved, helping the civil population in Vranje and the surrounding area. The final phase of Dr Hutton's mission in Serbia was her six-month stay in Belgrade where she established a city hospital and a camp colony on the nearby mountain of Avala. When in the spring of 1920 a decision was made that the Scottish Women's Hospitals Organization would end its work in Serbia, Dr Hutton left for Crimea, to take care of the sick and wounded in the Russian Civil War. Later that year the White Army was defeated and, together with the civilians who supported it, evacuated to Constantinople. Dr Hutton accompanied them and in 1921 returned to Britain, to resume her post at the Royal Edinburgh Hospital.

Dr Hutton's urge to write a story of her war experience in Serbia stems from her awareness that few books about World War I depict the liberation of Serbia (and the defence of Crimea) and that even fewer treat the feelings of "the gallant souls who suffered alike in victory and defeat" (Hutton 1928: 14), as books about World War I deal predominantly with politics. Her "account of the daily life of a women's unit at the Front" is or should be "novel", she believes. It is also very personal, as she makes use of the diary she kept at the Front and the letters she wrote home. Contrary to what so many British and other Western European sources of the time would have us believe, the Serbs emerging from the pages of Dr Hutton's book show as brave, patriotic and self-sacrificing, while their country, despite devastation and poverty, is described as beautiful. Her unit's highly professional, painstaking, methodical work and enormous 
energy also permeate the pages of Dr Hutton's travelogue; their enthusiasm in the face of trouble and resolute performance in unbearable conditions considerably contribute to the Serbian Army's final success. Serbian heroism and British resourcefulness, united towards a common goal, resulted in a triumph we are proud of even today, a hundred years later.

Dr Hutton's travelogue offers plenty of remarks about the Serbian soldiers, civilians and the way of life, as well as of the natural beauties of Serbia. When the author first sees the Serbian soldiers in Gevgelija, she says they are good-looking men but thinks their clothes are "quaint" as they wear "home-spun suits braided with black silk, opanke (sandals) of camel skin on their feet" and "round sheepskin caps". "These were the wonderful Serbian soldiers we Scottish women had all heard about, and certainly they were fine-looking men, bronzed, clear-eyed, tall, thin of flank, and with a longstepping, free gait" (Hutton 1928: 45). Half a year later, in Thessaloniki in May 1916, she meets the Serbs who have survived the tragic retreat over the Albanian mountains and managed to recover. Their appearance inspires the following impression:

How different the Serbian soldiers looked now! Gone was the picturesque native dress of the reservists, and all were now rigged out with British uniforms, American boots and puttees and French rifles, but they still clung to the characteristic Serbska kappa, though now made of khaki cloth. How handsome they looked, tall, lithe, and straight-limbed, men who had led an open-air life summer and winter, men of the hills and of the big, open spaces, with strong frames, fine eyesight, and great, white, healthy teeth; men accustomed to ride or walk their fifty odd miles a day and think nothing of it, and to live on very little food and even to go without it for long periods. Is it any wonder that those who are able to judge have pronounced them to be the finest soldiers in the world? (Hutton 1928: 77)

Dr Hutton also mentions the Serbian soldiers' love for their country which she became aware of at the Thessaloniki hospital, where the Serbs were treated from malaria and dysentery.

They were sad, highland people, and spoke of nothing but their beautiful country and of the selo (village), and they dreamt day and night of going kod kutche (home). There were no rivers or mountains, no birds or flowers - in fact, no sun or moon, like that of Serbia. They sang plaintive songs, some of them the old pesme (epic poems), centuries old, telling of 
the deeds of their great heroes; some, however, were quite modern and recounted the events of the past few months, verses being added from day to day as the time went on. One of the songs that became most familiar to us Britishers was "Tamo Daleko", which was written in Corfu. (Hutton 1928: 77)

Another memorable feature of the Serbs is their being good patients: "They made wonderful patients, quite unlike any we had ever nursed; they rarely complained and suffered pain marvellously, and often asked to be operated upon without an anæsthetic" (Hutton 1928: 86). The civilians who became Dr Hutton's patients in Vranje when the war ended were alike: "they never dreaded the pain of a dressing or felt the slightest apprehension before an operation" (Hutton 1928: 193). What is more, they put enormous faith in the Scottish doctors:

The Serbs never for a moment questioned our opinion or our skill; it was strange that this should be so in a land where women till the fields, where the man is the lord and master and rides while the woman walks by his side. One would break the news as gently as possible that an eye or a limb would have to go; "ne mari nishta" (it doesn't matter), they would say unconcernedly, "if you think so, then just away with it". Even the little children feared nothing, and were very stoical over their after-operation dressing. Indeed, they were super-patients such as one seldom or never sees among more highly civilized races. (Hutton 1928: 194)

"Civilized" seems to be the word which draws attention here, as it points to traces of Balkanism in Dr Hutton's discourse. She makes a distinction between civilized and uncivilized countries and nations in a few more instances in her travelogue. While staying in Thessaloniki upon retreat from Gevgelija and witnessing preparations of the Serbian Army for an offensive to the north, she writes of Greece: "The country was uncivilized to the extreme, and the people were so oriental and the conditions so elemental that it was indeed difficult to remember that it was in Europe" (Hutton 1928: 75-76). In her later descriptions of the Serbs' way of life in peaceful circumstances and their harvest celebrations she claims they are happy.

And why so happy? Is it not that they are near to Nature and know her secret, obey all her laws and take their simple pleasures in song and dance? After living in Serbia one cannot help realizing very forcibly that half our worries and illnesses, and possibly even diseases, may be due to 
over-civilization. The Serbs come into the world without difficulty and grow up without needing much more. (Hutton 1928: 203)

Her Serbian patients' endurance and courage is once again put down to a difference between the civilized and uncivilized nations: "This may be attributed in part to the healthy normal open-air life they had lived, without stress or strain, untrammelled by the difficulties which we civilized people make for ourselves throughout life. Except for occasional wars and pestilences, which were taken very much as a matter of course, their lives had been very uneventful" (Hutton 1928: 86). In the same manner, the Serbs' calmness before an operation or lack of dread of a dressing is explained as follows: "One was forced to the conclusion that they did not feel pain ${ }^{1}$ to the same extent as more highly civilized peoples. The whole nervous system seemed to be wonderfully stable, and they did not seem to feel in the least the mental strain of the war" (Hutton 1928: 194).

In other instances, however, the things which she has learnt or seen in the Balkans look like advantages when compared to the circumstances in her home country. Remembering the hardships and shortages at the Thessaloniki hospital upon retreat from Gevgelija, Dr Hutton writes: "We all learned, however, in war-time, especially in the Balkans, that everything could be well done with much less apparatus than we had previously thought necessary" (Hutton 1928: 59). Shortages of specialists in the Vranje hospital made Dr Hutton competent in many fields of medicine: "I soon found myself doing major operations which I had never thought would fall to my lot, and, as the cases were varied and general, we had to do all the operations that, at home, would be handed over to specialists in a particular line" (Hutton 1928: 191).

Commenting on the Serbian weddings to which she was frequently invited, she praises the rational attitude of the Serbian girls: "It never occurs to them to wonder whether they will be happy or whether they will be suited to each other, nor do they expect the blissful happiness that most English girls do when they marry. They wed because it is the natural course of events, settle down at once and produce a healthy child every year" (Hutton 1928: 203). She notices that childbirth was also considered "the natural cause of events" and that nobody ever asked for a doctor's help in these cases: "The process of childbirth seems always to be easy and sometimes indeed painless, and it is treated as a most ordinary natural event instead of an illness, as it is apt to be with us" (Hutton 1928: 198).

In line with this, many other details in Dr Hutton's travelogue show her openmindedness and affinity for the Serbs. Together with nurses and other doctors from her unit she would join her patients in the kolo line, the national dance of the Serbs which

${ }^{1}$ My emphasis. 
they adored and danced even though wounded: “...the halt and the lame struggled to their feet", writes Dr Hutton, "and the sick stealthily crept out of bed and one by one joined in the line of dancers" (Hutton 1928: 89). Living with the Serbs, she had a chance to learn about their epic poems and the value they had for the nation in the long centuries of the Ottoman occupation, but also to witness the making of new poems about contemporary events: "The songs are not all ancient and some new ones were made even during the Balkan Wars and the Great War, telling of the retreat across Albania, the resting at Corfu, the storming of Kaimakchalan in 1916, and of the glorious advance in 1918" (Hutton 1928: 92). Like other British subjects who spent World War I serving in Serbia, Dr Hutton also acquired a basic knowledge of Serbian history, traces of which are evident in her book. She writes about the battle on the "Field of Kossovo", the hero whom she calls "Kralyevitch Marko", the final fall of Serbia under the Ottoman rule (the years are incorrect, though) and the hard times of the subjugation during which the Serbs' only stronghold was their Church. The two uprisings against the Turks in the early nineteenth century are also mentioned, together with their leaders -"Kara George" and "Milosh Obrenovitch" - the founders of the royal dynasties. The tragic extinction of the Obrenović dynasty in 1903 is characterized as "an event which shook Europe and resulted in Serbia being practically ostracized for a time" (Hutton 1928: 93).

With many details, Dr Hutton describes the Serbian slava - the most important feast day in every family - the way her patients celebrated it in war and the many occasions on which she was a guest of honour in Serbian homes in Vranje in the postwar days. She also made friends with several notable Serbs - Colonel Sondermajer, Captain Milan Jovičić and Colonel Nikolajević - who could speak good English and whose professional and stalwart bearing in dire circumstances greatly impressed her. Just as she was present at many weddings, she was invited to christenings and was "in great demand as Kuma" (Hutton 1928: 204). Understandably, there were many funerals in Vranje at the time when her hospital was established there and she attended these ceremonies as well, leaving detailed descriptions of the rituals.

In return for Serbian kindness, Dr Hutton gave several tea-parties at the hospital and invited townspeople from Vranje who would come in their best clothes and enjoy socializing, listening to lively music played by a Gipsy band. Prompted by her goodlooking and joyful guests, Dr Hutton makes a comment free of the distinction she had made on previous occasions between civilized and uncivilized nations: "... and all the townspeople came dressed á la Vogue, and looked like a garden-party crowd from anywhere in the world" (Hutton 1928: 210).

Typical of the British, Dr Hutton shows herself to be a great lover of nature. The Balkans, although devastated by war, offered many natural sights pleasant to her 
eye and remindful of home. Just before the retreat from Gevgelija to Thessaloniki, in December 1915, she wrote: "We were sad at having to leave that lovely countryside where we Scots felt so much at home. It is true that the village was Turkish, the natives Macedonian and the country Serbia, but the mountains were 'the mist-covered mountains of home', and we loved their ever-changing tints and the rolling mists. The swiftly rushing Vardar, too, was at this point very reminiscent of our Scottish rivers" (Hutton 1928: 52). Much later, in early 1919, Dr Hutton writes a eulogy for the Serbian spring with an enthusiasm comparable to that of Chaucer's and his idea of the season's vital energy:

Magical Serbian April, not so exotic as that of Macedonia, but more lingering, fragrant and exquisite! And with it our garden, which we did not seem to have noticed before, became a bower of plum and peach blossom, and when the lilacs slowly opened their dusky buds, there was never a garden so sweet as ours. Primroses and cowslips bloomed on the green hillsides around us, and we walked in the valleys on carpets of white and purple violets under arches of cherry-blossom. The Serbians seemed to get the spring into their bones, and tears and lethargy suddenly gave place to smiles and activity. (Hutton 1928: 188)

Finally, the spring enables her to see that her Serbian patients did not exaggerate in the descriptions of their homeland while they dreamt of it during war: "Before we had worked for a year in Vranja I had realized that Serbia was indeed that enchanting, joyous country of which the exiled warriors had spoken so often and of which they had sung with so much longing in "Tamo daleko" (Hutton 1928: 202).

Before leaving Vranje, Dr Hutton was allowed to organize a fifty-bed hospital there. A building was provided and the hospital completely furnished, including a laboratory and operating-theatre. She also organized three smaller hospitals at the nearby towns of Vladičin Han, Surdulica and Vranjska Banja. Her rapport with the Serbs is best summarized in the following words: "It was during these years that we got to know and understand the Serb soldier, to appreciate his worth and to learn something of the story of Serbia, ancient and modern. We learnt to have an affection for these simple men and to sympathize and grieve with them in the loss of their country and all that it held for them" (Hutton 1928: 82).

The Serbs, on their part, expressed their gratitude in many ways. The Belgrade newspapers regularly published articles on the Scottish Women's Hospital in Vranje. One in the Evening News dated February $17^{\text {th }} 1919$ describes it as follows: 
The sanitary conditions there prevailing, the professional medical skill, the ministering tenderness of the sisters, the love that was displayed towards everybody for fully two years - all that shall be an unbesmirched memory to every Serbian soldier who lay ill at that hospital, for all that gave him strength and encouragement to endure in the terrible struggle in which he suffered so much. ..... Let their country be proud of them, for they are deserving of honour in full measure, and the Serbian soldier shall remember them with great thankfulness. (Hutton 1928: 200-201)

And Serbia does remember. Dr Hutton received the Order of Saint Sava and the Order of the White Eagle. In 2011 a nursing high school in Vranje was named after her and in 2015 a Serbian postage stamp was released to honour her work during the war.

We are indebted to Dr Hutton for her work in Serbia and her book about it. Having come to this country to learn about it and help it, Dr Hutton challenged an unfavourable reputation it had in the British public. Traces of Balkanism which permeate her travelogue seem to have been overcome during her five-year stay in Serbia and due to her first-hand experience with this country. And overcoming prejudice is said to be the faculty of open-minded, kind-hearted and altruistic individuals.

\section{References}

Haton, I. E. (2018). Sa ženskom jedinicom u Srbiji, Solunu i Sevastopolju. Novi Sad i Beograd: Prometej i Radio-Televizija Srbije.

Hutton, I. E. (1928). With a Woman's Unit in Serbia, Salonika and Sebastopol. London: Williams and Norgate Limited.

Kostić, V. (1972). Kulturne veze između jugoslovenskih zemalja i Engleske do 1700. godine. Odeljenje literature i jezika, knj. 22. Beograd: Posebna izdanja Srpske akademije nauka i umetnosti, CDLVIII.

Kostić, V. (2014). Britanija i Srbija: kontakti, veze, odnosi. Beograd: Arhipelag. Todorova, M. (2009). Imagining the Balkans. Oxford: Oxford University Press. 